\title{
ル・コルビュジエの「小さな家」における空間構成と熱・光環境の関係 RELATIONSHIP BETWEEN SPATIAL COMPOSITION AND THERMAL AND LIGHT ENVIRONMENT IN LE CORBUSIER’S “UNE PETITE MAISON”
}

\author{
金子尚志 ${ }^{* 1}$, 小泉雅生 ${ }^{* 2}$, 松元 良枝*3, 武政 孝治*4 \\ Naoshi KANEKO, Masao KOIZUMI, Yoshie MATSUMOTO \\ and Koji TAKEMASA
}

\begin{abstract}
This study examines features related to architectural planning and environmental control such as spatial features and the composition of the horizontal continuous window surround in Le Corbusier's "Une Petite Maison". In addition, the thermal and light environment produced by simulation software for the main rooms will be examined. It will reveal the relationship between Le Corbusier's architectural ingenuity and environmental control over the environment and some of the thinking that led to contemporary passive design which was active in an era before the building performance of the outer skin and equipment was inadequate and the energy was plentiful and stable.
\end{abstract}

Keywords : Passive design, Spatial composition, Le Corbusier, Thermal environment, Light environment, House パッシブデザイン, 空間構成, ル・コルビュジエ, 熱環境, 光環境, 住宅

\section{1. 序論}

\section{1. 研究の背景と目的}

持続可能な社会の実現に向けて、国連によって SDGs（持続可能 な開発目標)・17 のゴールが提示され、建築分野では、省エネルギー 化、温室効果ガスの削減、省資源化が世界的な取り組みとなっている。 日本でも、特に住宅の分野においては、消費エネルギーが増加傾向 にあることから早急な対応に迫られている ${ }^{1)}$ 。1979 年の省エネ法制 定以降、住宅に関する様々な施策などの取組みがなされてきた。し かし、省エネルギーと建築デザインの統合の視点でみると、自然エ ネルギーを活用し、機械設備の依存を出来る限り減らすだけでなく、 地域性と身体感覚を重視したパッシブデザインは、これからの環境 の時代に必須の手法となっている。

住宅における機械設備導入の黎明期において多くの作品を残し、 近代建築の巨匠と呼ばれる建築家のひとりに、ル・コルビュジエ（Le Corbusier，1887-1965）がいる。広く知られているル・コルビュジ エの建築設計に関する概念や手法には、近代建築の 5 原則注 1)、ブリー ズ・ソレイユ、モデュロール等があり、構法の面でも、伝統的な石 組みやレンガ積みから鉄筋コンクリート構造への変化の端緒を開き、 多くの建築作品を残している。ル・コルビュジエの作品を環境的配 慮の観点で概観すると、環境を制御するための建築的な工夫をデザ インに統合している例が見られる。その代表例として、自然採光の 事例では、オザンファン邸（1924 年）注2)、自然通風及び開口の工夫 ではサラバイ邸（1951 年） 注3)、また、太陽光の制御ではクルチェッ
卜邸（1949 年） 注4) がある。これらの作品とともに、多くのスケッ チからも、太陽軌道と建築の関係を考慮していたこと ${ }^{3)}$ を䙼うこと ができる (Fig.1)。現代では一般的となった、ダイアグラムによる太 陽の位置や通風の関係を断面で示寸表現を 20 世紀の早い時期から採 用していた。また、身体感覚と自然エネルギーの活用に関する記述 もみられる注5)。パッシブデザインの概念が登場するのは 20 世紀半 ば以降であり、ル・コルビュジエが設計活動を始めた当時は、20世 紀初頭に流行していたスペイン風邪の影響や、密集化する都市部に おける環境改善や健康への配慮から、自然採光、自然通風の活用が 意図されていたと考えられる。しかし、前述した自然採光や自然通 風などの建築的工夫や、断面のダイアグラムの表現などは後年に普 及するパッシブデザインに少なからず影響を与えたと考えられる。

ル・コルビュジエの初期の作品である両親のための住宅「小さな 家 (Une Petite Maison, 1923，以下、小さな家)」は、設計を先に行い、 その後、最適な敷地を探して建てられた ${ }^{5)}$ 。両親のために設計した住 宅であることや、初期の作品であることもル・コルビュジエがその 後に展開していくデザインのコンセプトが強く表れていると考えら れる。計画の第 1 条件が「太陽が南にあること」 ${ }^{5)}$ と述べているこ とからも太陽と建物の関係を重要視していたことや、建築的工夫と 環境制御の統合を意図していたこと主6) も覗える。

そこで本研究は、ル・コルビュジエの「小さな家」を対象に、空 間的な特徴の把握と、居間などの主要な室について、シミュレーショ

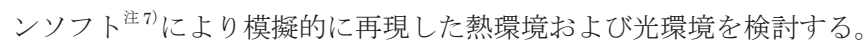

\footnotetext{
*1 東京都立大学都市環境科学研究科建築学域 博士後期課程 · 修士(芸術工学)

*2 東京都立大学都市環境科学研究科建築学域 教授・博士 (工学)

*3 侏)アアト口 博士(工学)

*4 LEAD Labo. 主宰・博士(工学)
}

Doctoral Student, Dept. of Architecture, Tokyo Metropolitan University, M.Design

Prof., Dept. of Architecture, Tokyo Metropolitan University, Dr.Eng. Quattro Corporate Design, Co., Ltd., Dr.Eng. Leader, LEAD Labo., Dr.Eng. 
外皮の建築性能や機械設備が十分ではなく、エネルギーが潤沢に安 定供給される以前の時代に活躍した、ル・コルビュジエの環境に対 する建築的工夫と環境制御の関係、現代のパッシブデザインにつな がる思考の一端を明らかにすることを目的とする。

\section{2. 既往の研究}

これまでになされてきた学術的な研究において、ル・コルビュジ エをテーマとしたものの多くは設計理論や空間構成に関するもので、 空間と環境の関係を論じたものは少ない。そのうち、ル・コルビュ ジエの建築色彩理論と環境概念について分析したもの ${ }^{6)}$ では、室内 環境を構成する主要な要素である色彩に関して、ル・コルビュジエ の色彩表現と光環境との関係を読み解いている。また、チャンディ ガール州都計画におけるル・コルビュジエの住宅構想に関する土着 的な要素を取り入れた住宅設計について分析したもの ${ }^{7)}$ では、ル・ コルビュジェの気候風土への対応と地域性を設計に活かす視点を示 している。これらはいずれも、パッシブデザインの視点からル・コ ルビュジエの空間を考察する上で、有用な知見を与えている。

また、環境やパッシブデザイン、住宅及び建築設計の関係に着目 したもののうち、環境配慮型住宅の技術と空間設計手法を類型化し たもの ${ }^{8)}$ 、現代住宅の事例をもとにパッシブ手法の複合性、相互関係 性を季節の違いと手法によって分類したもの ${ }^{9)}$ があり、パッシブ手 法と空間の関連について有益な視点が提供されている。また、自然 採光を活用する設計手法の実例をもとに空間特性を考察したもの ${ }^{10)}$ では、コンピューターシミュレーションが普及する前の時代におけ る光空間と原理の考察過程について示されている。さらには筆者ら の気候図の作成とパッシブデザインの設計手法を示したもの ${ }^{11)}$ では、 気候とパッシブデザイン手法との関係を読み解く視点を示している。 これらはいずれも住空間と環境との関係を考察する上で重要な視座 を提供している。

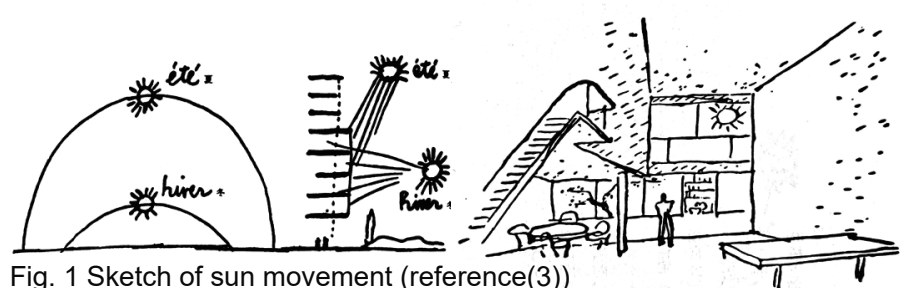

Fig. 1 Sketch of sun movement (reference(3))

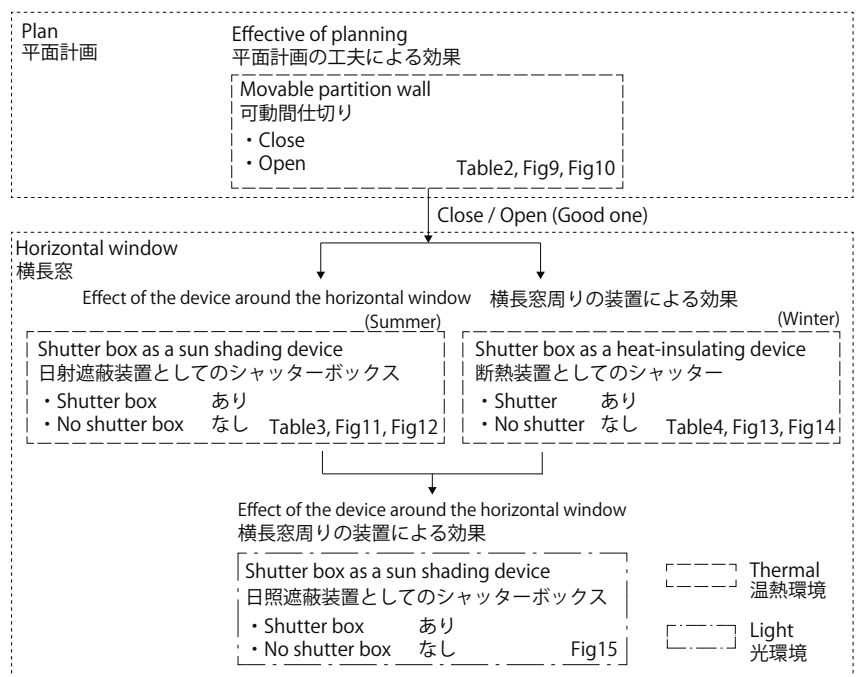

Fig. 2 Environmental simulation flow
これらの既往の研究に対し、本研究のように、パッシブデザイン の概念が広く認識される以前の時代に、ル・コルビュジエの初期の 作品「小さな家」に着目し、熱と光の観点から空間と環境の特徵を 見出した既往研究はみられない。本研究の成果は、一般的にはデザ インの視点で評価されることが多いル・コルビュジエの住宅作品に おいて、空間構成と環境配慮の手法の関係について、パッシブデザ インの視点から考察を与えるとともに、現代の住宅設計における環 境配慮とデザインの統合に関して有用な知見を与えるものと考える。

尚、本論文は 2020 年度日本建築学会大会学術講演 ${ }^{12)}$ の発表内容に、 加筆・修正を加え作成したものである。

\section{3. 研究の方法と概要}

「小さな家」は、1923 年の竣工後、改修や増築がなされているが、 本研究では、竣工時の状態を対象と寸る。入手可能な平面図、断面図、 立面図、現地調查による写真など分析に十分な資料注8) をもとに、分 析用の図面を作成し、主要な生活の場として居間を含む空間（以下、 主空間注 9) $)$ に着目して分析する。

序論に続き 2 章では、「小さな家」が立地する環境条件に着目し、 建設地周辺の気候条件、室内環境に関係する要素として、建築計画 概要と躯体構成を検討する。 3 章では、 2 章での検討に加え、空間構成、 開口部に着目し、主空間の熱環境を自然室温のシミュレーションに より検討する。 4 章では、主空間における自然光の光環境をシミュレー ションにより検討し、光環境と空間の関係を検討する。シミュレー ションのフローを Fig.2 に示す。

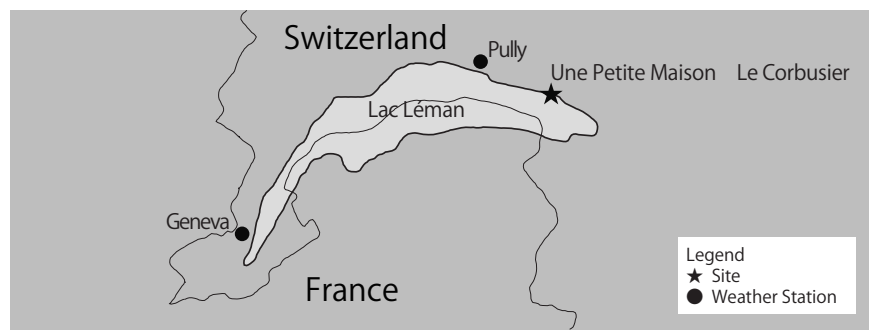

Fig. 3 Site and weather station

Pully
Time 時刻
01
24
22
22
221
20
20
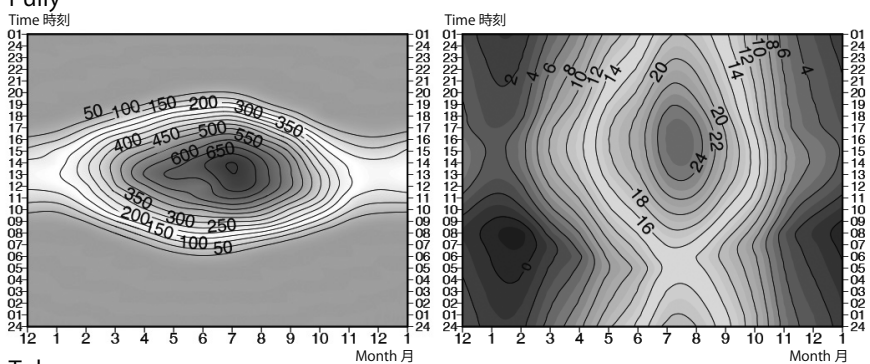

Tokyo

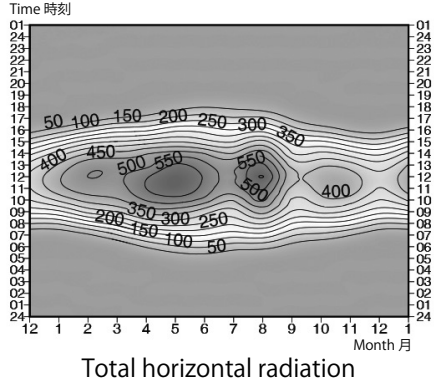

Total horizontal radiation
水平面全天日射量 $\left(\mathrm{W} / \mathrm{m}^{2}\right)$

Fig. 4 Passive climate chart

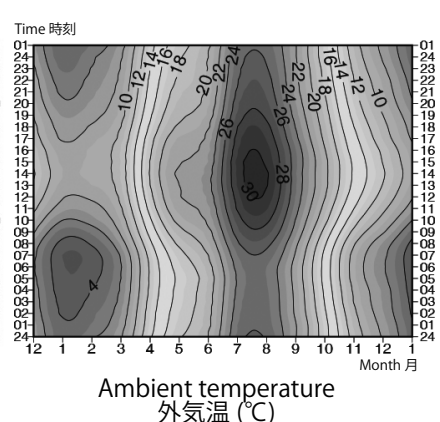

Fig. 4 Note: In the figures, Vertical axis represents time, Horizontal axis displays month 図 4 注）図中の縦軸は時間、横軸は月を示す。 


\section{2. 気候特性と建築的手法}

\section{1. 気候特性}

パッシブデザイン手法は建物が立地する場所の特性に大きく関係 する。そこでまず、建物が立地する周辺環境の特徵として気候条件を 整理する。「小さな家」は、スイス南西部のコルソー（Corseaux）地 方に位置し、フランスとの国境に跨るレマン湖の湖岸に建つ (Fig.3)。

年間を通した気候特性を把握するため、パッシブ気候図 ${ }^{11)}$, 注 10 ) 検討に用いる。パッシブ気候図は、縦軸に時刻、横軸に月を示して おり、年間及び時刻別の変動やその程度を等值線や色で認識するこ とが可能で、その状態によって適したパッシブ手法を検討するもの である。対象地点は、建設地から約 $14 \mathrm{~km}$ 西、レマン湖にほど近い 気象地点ピュリー (Pully) とした。温熱環境と光環境の観点から外 気温と水平面全天日射量について、ピュリーのデータをもとにパッ シブ気候図を作成した（Fig.4）。なお、比較のため、東京のデータを 併記した。

日射量をみると、ピュリーでは、 $450 \mathrm{~W} / \mathrm{m}^{2}$ を下回る日射量が少 ない期間が 10 月から 3 月で、中でも 11 月中旬から 1 月中旬まで の約 3 力月間は、日中、 $200 \mathrm{~W} / \mathrm{m}^{2}$ を下回る注 ${ }^{11}$ 。また、日射量が $550 \mathrm{~W} / \mathrm{m}^{2}$ を超える期間は 5 月から 9 月上旬で、 6 月中旬から 8 月 中旬の日中はさらに多く、600W/ $\mathrm{m}^{2}$ を超える。7 月の 2 時頃には

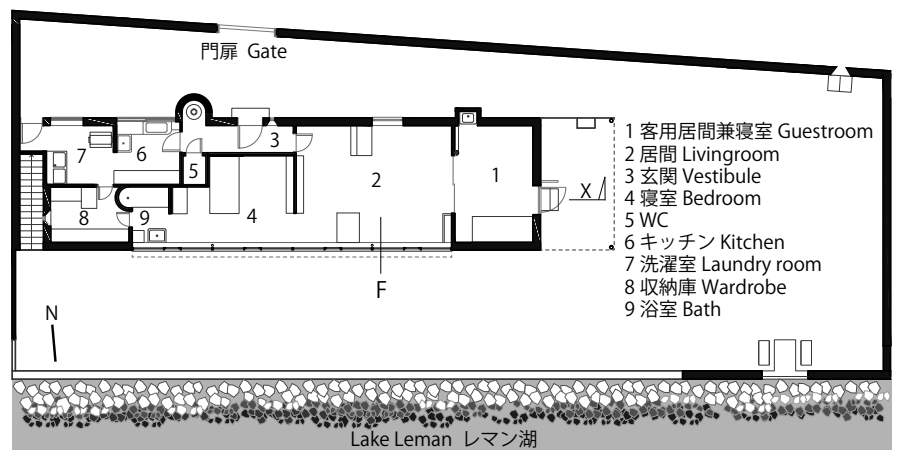

Site plan and $1 \mathrm{~F}$ plan 配置図兼 1 階平面図
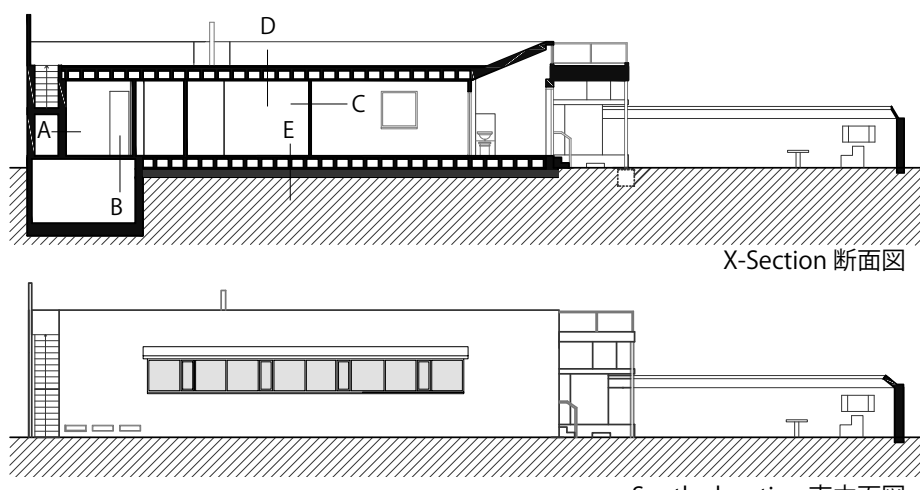

Fig. 5 Plans (Drawing by N. Kaneko, 2019)
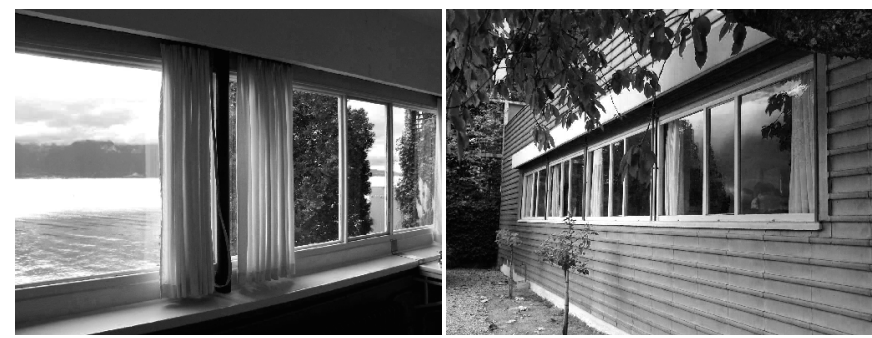

Fig. 6 Interior and exterior (Photograph of N. Kaneko, 2007)
$700 \mathrm{~W} / \mathrm{m}^{2}$ 超える。対して、東京の日射量は $450 \mathrm{~W} / \mathrm{m}^{2}$ 以下となる 期間は 9 月から 1 月中旬までで、 $350 \mathrm{~W} / \mathrm{m}^{2}$ を下回らない。夏期は $550 \mathrm{~W} / \mathrm{m}^{2}$ 程度の日射量である。以上から、ピュリーは東京と比較す ると冬期の日射が少なく夏期の日射が多いことがわかる。また、パッ シブ気候図の中心が縦方向に膨らむ等值線の形であることから、夏 と冬の日射量の差が大きく、時刻による差もあると考えられる。

一方、外気温をみると、ピュリーは、夏の日中、 $25^{\circ} \mathrm{C}$ 程度まで上昇し、 冬期の夜間は $0^{\circ} \mathrm{C}$ を下回る。ピュリーの気候特性として、夏期の日射 量は多いものの、最高気温は $25^{\circ} \mathrm{C}$ 程度までであり、比較的、過ごし やすい注 12)。しかし、冬期は日射が少なく、零下を大きく下回らない ものの低い気温が続くことが特徴である。このような気候特性の場 合、夏期は日射遮蔽、冬期は熱損失の低減や、室内の気積を小さく するといったパッシブデザイン手法が有効であると考えられる。

\section{2. 建物概要}

敷地は北側に道路、鉄道、緩やかな斜面にはブドウ畑が続き、南 側にはレマン湖が広がる。「小さな家」は、幅 $16.75 \mathrm{~m}$ 、奥行き $4.5 \mathrm{~m}$ でレマン湖を南にしてほぼ東西軸に長い矩形の平面である (Fig.5)。 南壁面にはこの住宅の特徴となっている横長の水平に連続する空（以 下、横長空注 13) $)$ があり、この横長空からはレマン湖対岸の北アルプ スの景色を広い視野角で望むことができる（Fig.6）。東端に客用居間 兼寝室、中央には居間、寝室及び浴室、西端に収納庫、その北側にキッ
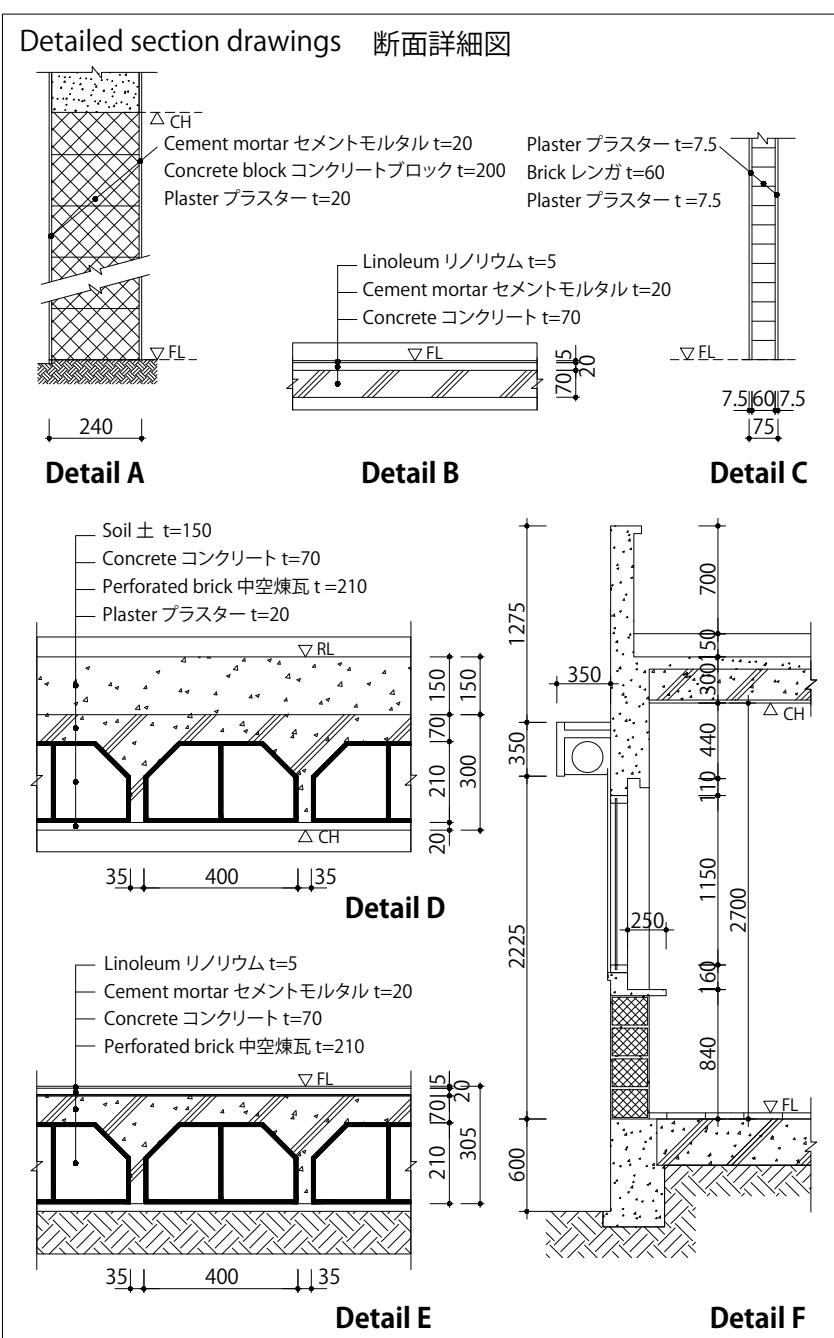

Fig. 7 Detailed section drawings (Drawing by N. Kaneko, 2019) 
チン、トイレなどから構成されており、寝室、トイレ、浴室の周り を回遊できるコンパクトに計画された平面となっている。東端部の ピロティのような大きい軒下空間、緑化された屋上庭園、回遊性の あるプラン、幅約 $11 \mathrm{~m}$ の横長空、構造的な制限を受けないファサード、 これらは近代建築の 5 原則 ${ }^{(i) 1)}$ における萌芽的要素と考えられる。

環境制御の工夫として、開口部は、リビングに床から $1,000 \mathrm{~mm}$ の 高さに、幅 $10.75 \mathrm{~m}$ ・高さ $1.15 \mathrm{~m}$ の横長空が設けられているほか、 北側には幅 $1,690 \mathrm{~mm}$ 、玄関横に $200 \mathrm{~mm}$ 、キッチン北側に $1,150 \mathrm{~mm}$ と $1,975 \mathrm{~mm}$ 、収納庫西側に $200 \mathrm{~mm}$ 、高さ方向はいずれも横長空に 揃えて床から $1,000 \mathrm{~mm}$ の位置から、高さ $1,150 \mathrm{~mm}$ である。客用居 間兼寝室には幅 $2,000 \mathrm{~mm}$ 、高さ $500 \mathrm{~mm}$ の東向きハイサイドライト と、幅 $1,000 \mathrm{~mm}$ 、高さ $2,100 \mathrm{~mm}$ の外部への出入り用ドアがある。 北側に配置されたキッチン、西側の収納庫、及び外壁に面さない卜 イレにそれぞれトップライトが設けられている。また、全体床面積 約 $71 \mathrm{~m}^{2}$ に対して、建具や可動間仕切りの工夫で閉じることによって $39 \mathrm{~m}^{2}$ の居間、寝室及び浴室のみの空間となり、約 $54 \%$ に縮小寸るこ

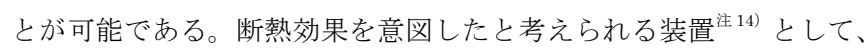
横長空の室内側にはカーテンボックス、その屋外側にはシャッター がシャッターボックスとともに設けられている。一方、機械設備と して、暖房システムが横長空に沿って設けられた奥行き $250 \mathrm{~mm}$ の 空台の下に設置されている。また、西側敷地境界に沿って設けられ た西日除けとみられる格子状の塀がある。

\section{3. 構法・素材の特徵}

「小さな家」の構法的特徵として、コンクリートブロックの外壁 と中空煉瓦を用いたスラブによる構法が挙げられる注 15) (Fig.7)。著 書の中で「施工業者に任せざるをえなかった」 ${ }^{5)}$ と、躯体の構成にや や否定的な記述が見られるが、中空煉瓦を用いたスラブ構成は、当 時は一般的な構法、素材として使われていたと考えられる注 16)。地震 力を大きく見込まなければならない日本と異なり、コンクリートブ ロックの外壁に中空煉瓦を用いたスラブによる構法でも成立するた

\begin{tabular}{|c|c|}
\hline Building shape model & 形状モデルの作成 \\
\hline Target house & 対象建物 \\
\hline - Multizone building modeling & ·多数室モデルとして解析 \\
\hline - Not include staicase shape & ・階段の形状は含まない \\
\hline -Azimuth angle/5 degree & - 方位角 $5^{\circ}$ \\
\hline Boundary between zones & ゾーンの境界 \\
\hline $\begin{array}{l}\text { - Boundary without surface is set as air } \\
\text { exchange with } 20 \text { times/hour (combined with } \\
\text { the adjacent room) } \\
\text {-The ground boundry surface is set to the } \\
\text { ground temperature }(0.5 \mathrm{~m}, 1 \mathrm{~m}, 2 \mathrm{~m}) \\
\end{array}$ & $\begin{array}{l}\text { ・間仕切がない場合の室間換気は } \\
\text { 隣室との } 2 \text { 室の合計容量の } 20 \text { 回 } / \mathrm{h} \\
\text { •地面と接する場合の境界温度は } \\
\text { 地中温度を設定 }(0.5 \mathrm{~m}, 1 \mathrm{~m}, 2 \mathrm{~m})\end{array}$ \\
\hline Construction & 構法 \\
\hline $\begin{array}{l}\text {-Set the material composition of each element } \\
\text {-Solar absorptance/inside and outside surface }\end{array}$ & $\begin{array}{l}\text { ·各部位の材料構成を設定（床、壁、 } \\
\text { 天井、屋根、開口部等） } \\
\text { • 日射吸収率 / 室内外に設定 }\end{array}$ \\
\hline Weather data(Meteonorm) & 気象データ (Meteonorm) \\
\hline - Location/Pully (Switzerland) & ・場所 / スイス (Pully) \\
\hline$\cdot$ - Longitude \& Latitude $/ 46.52^{\circ}, 6.67^{\circ}$ & • 緯度と経度 $/ 46.52^{\circ} ， 6.67^{\circ}$ \\
\hline Lighting \& Air conditioning \& Infiltration & 照明・空調・換気 \\
\hline - Lighting device/none & ・照明 /なし \\
\hline - Air conditioning/none & ・空調 / なし \\
\hline$\cdot$ Internal gain/none & • 内部発熱 / なし \\
\hline$\cdot$ Infiltration/1.2 times/hour & • 換気 $/ 1.2$ 回 $/ \mathrm{h}$ \\
\hline - Sensible heat capacity of furniture $/ 18.8 \mathrm{~kJ} / \mathrm{m}^{3} \mathrm{~K}$ & • 家具の顕熱容量 $/ 18.8 \mathrm{~kJ} / \mathrm{m}^{3} \mathrm{~K}$ \\
\hline Simulation software & シミュレーションソフト \\
\hline$\cdot$ TRNSYS 18 & $\cdot$ TRNSYS 18 \\
\hline
\end{tabular}

め、「小さな家」以降サヴォア邸をはじめル・コルビュジエ作品で用 いられている注16)。これらの構成は、自重を軽くして鉛直荷重を軽減 しているものと考えられる。南外壁面には直径 $8 \mathrm{~cm}$ の鋼管の柱が 2 力所設けられ、横長空を成立させている。温熱環境の視点でみると、 断熱材は用いられていないが、中空煉瓦の空気部分による断熱要素、 コンクリートブロックと、部分的に用いられていたコンクリートが 蓄熱部材として効果をもたらすと考えられる。緑化された屋上に関 して、「 $15 \mathrm{~cm}$ ないし $20 \mathrm{~cm}$ の土が盛られ (中略) 植物が小陰を作り 密集した根は断熱層をなす」 ${ }^{5)}$ とル・コルビュジエ自身が屋上緑化に 断熱性能を期待している。竣工後、外壁のクラックによって亜鉛鉄 板によって外壁が改修されているが、竣工時はプラスター仕上げで あった。東側の大きな軒庇は $6 \mathrm{~cm}$ の円形鋼管で支持されている。

\section{3. 熱環境と建築計画}

前章までの環境に配慮されていると考えられる設計手法のうち、 屋上緑化、空間の伸縮、横長空について、それぞれの熱環境におけ る効果を、熱貫流率の計算と主空間の自然室温をシミュレーション により検討する（Table1）。住戸全体を多数室モデルとし、各部位の 層構成にあわせてモデル化した注 17 。

\section{1. 屋上緑化の熱的効果}

屋上緑化の熱的効果を確認するため、Fig.7 の構成をもとに屋根面 における熱貫流率を算出した ${ }^{18)}$ 。土を盛っている場合の熱貫流率 $2.12 \mathrm{~W} /\left(\mathrm{m}^{2} \cdot \mathrm{K}\right)$ と比べて、土を盛っていない場合は $2.69 \mathrm{~W} /\left(\mathrm{m}^{2} \cdot \mathrm{K}\right)$ であり、熱の伝えにくさは約 1.3 倍となっている。その他の各部位の 熱貫流率は、外壁は $2.51 \mathrm{~W} /\left(\mathrm{m}^{2} \cdot \mathrm{K}\right)$ 、外壁上部は $2.98 \mathrm{~W} /\left(\mathrm{m}^{2} \cdot \mathrm{K}\right)$ 、

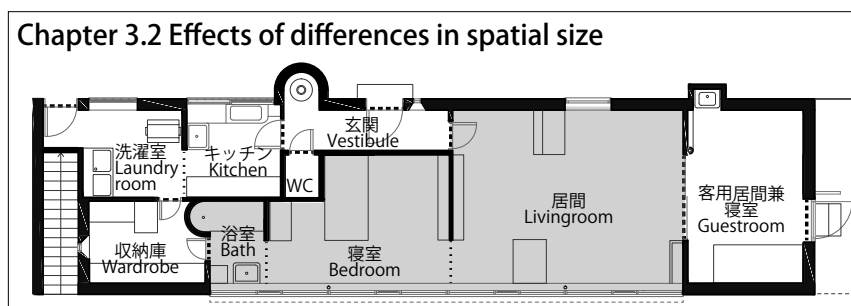

Close the door at all times (ドアを閉鎖・常時)

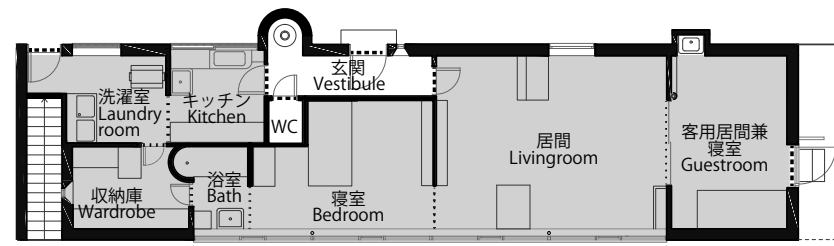

Open the door during the day (ドア開放・日中のみ)

Legend 凡例

Area connected to the livingroom 居間とひとつながりとなるエリア

...... No door (Always open) 常時解放 (ドアなし)

......... Openable door 開閉可能なドア

Chapter 3.3, 3.4 Effects of shutter box with shutter and curtain

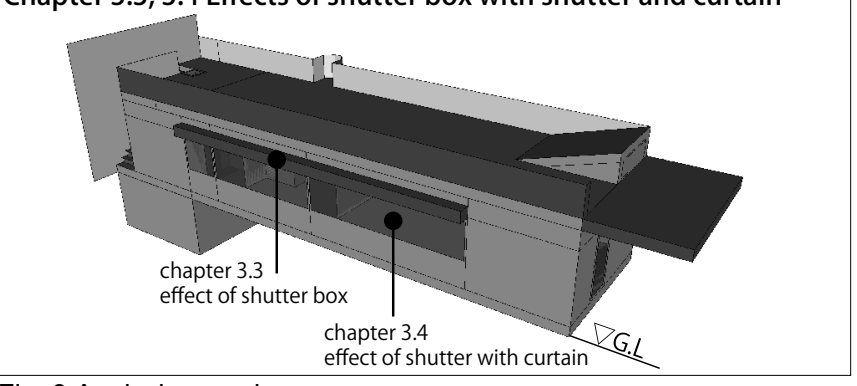

Fig. 8 Analysis overview 
床は $2.6 \mathrm{~W} /\left(\mathrm{m}^{2} \cdot \mathrm{K}\right)$ であり、これらと比べても土を盛っている場合 の熱貫流率は小さい值を示していることから、壁、床の断熱材がな い時代の有効な断熱手法と捉えることができる。

\section{2. 空間の伸縮による熱的効果}

住まい方に応じた空間の伸縮を可能にしている回遊性のある平面 は、この住宅の特徵とも言える。南側に居間を含む主空間、熱的バッ ファゾーンとなる空間を北側に配置していることから、時間、季節 に応じて建具や可動間仕切りを開閉することにより空間を伸縮させ、 室内の温熱環境をコントロールできたのではないかと考えられる。 そこで、空間の伸縮が室温変動及ぼす影響を確認する (Fig.8)。建具 や可動間仕切りを閉じ空間を小さくした場合 (約 $\left.39 \mathrm{~m}^{2}\right)$ とトイレ・ 玄関以外の扉を開けて空間を広げた場合（約 $71 \mathrm{~m}^{2} ）$ の居間の自然室 温を比較する。日中を 6 時から 18 時、それ以外を夜間とした。

年間を通して建具や可動間仕切りを開閉した場合の、居間における 室温の月別平均值を示す (Table2)。11月から 4 月まで室温は $10^{\circ} \mathrm{C}$ を下回る。建具や可動間仕切りを閉じて空間を小さくした場合と、 開いて大きくした場合のモデル間の温度差に着目すると (Fig.9)、12 月から 1 月は温度差が小さく、8 月から 10 月に温度差は大きくなる。 日射量が少なく外気温が低い時期の室温はいずれの場合も上昇せず モデル間の温度差は小さい。また、日射量が多く外気温が高い 7 月、 8月はシャッターボックスが庇として働いたために差が大きくなった とみられる。モデル間で温度差が最大になった 10 月下旬の一週間の 室温変動に着目すると（Fig.10）、10/27 の 16 時に最大で $1.6{ }^{\circ} \mathrm{C}$ 差 が見られた。室温は常に $20^{\circ} \mathrm{C}$ を回っており、日ごとに室温が下がっ てくる。10/26のように、日射が少なく外気温も低い場合はモデル

Table 2 Room temperature on monthly average (Chap.3.2)

\begin{tabular}{|l|l|l|l|l|l|l|l|l|l|l|l|l|}
\hline Month & 1 & 2 & 3 & 4 & 5 & 6 & 7 & 8 & 9 & 10 & 11 & 12 \\
\hline
\end{tabular} \begin{tabular}{|l|l|l|l|l|l|l|l|l|l|l|l|l|}
\hline Close & 2.2 & 2.9 & 6.5 & 9.8 & 13.9 & 17.4 & 21.3 & 21.2 & 18.0 & 13.4 & 7.3 & 4.2 \\
\hline Open & 2.0 & 2.7 & 6.2 & 9.5 & 13.7 & 17.2 & 21.0 & 20.8 & 17.5 & 13.0 & 7.1 & 4.0 \\
\hline
\end{tabular} \begin{tabular}{|l|l|l|l|l|l|l|l|l|l|l|l|l|}
\hline Open & 2.0 & 2.7 & 6.2 & 9.5 & 13.7 & 17.2 & 21.0 & 20.8 & 17.5 & 13.0 & 7.1 & 4.0 \\
\hline
\end{tabular} \begin{tabular}{|l|l|l|l|l|l|l|l|l|l|l|l|l|}
\hline Difference & 0.2 & 0.2 & 0.3 & 0.3 & 0.2 & 0.2 & 0.3 & 0.4 & 0.5 & 0.4 & 0.2 & 0.2 \\
\hline
\end{tabular}

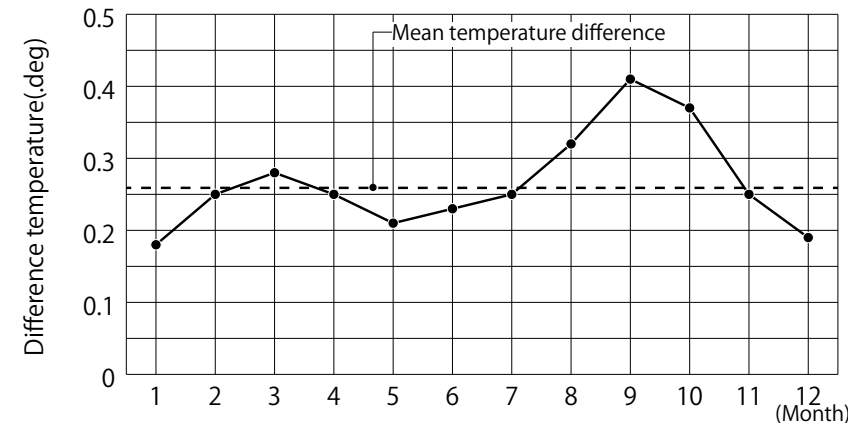

Fig. 9 Difference in monthly mean room temperature (chap.3.2)

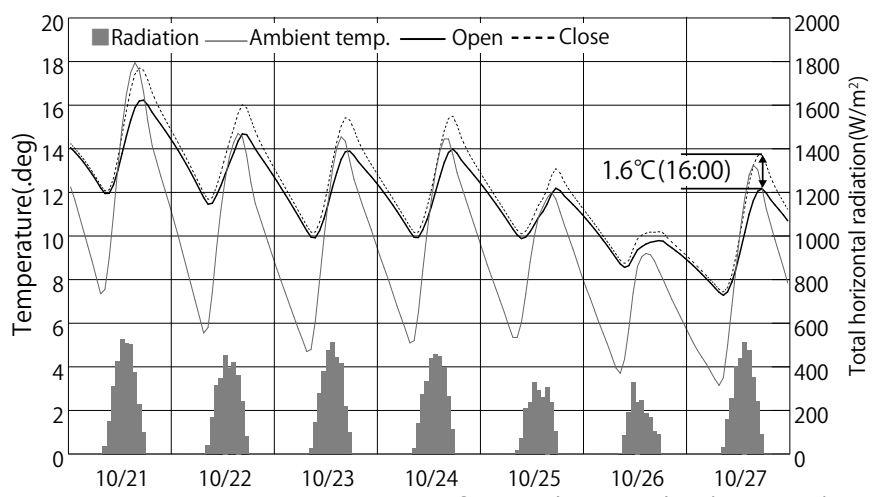

Fig. 10 Room temperature variation from $10 / 21$ to $10 / 27$ (chap.3.2)
Table 3 Room temperature on monthly average (Chap.3.3)

\begin{tabular}{|l|l|c|c|c|c|c|c|c|c|c|c|c|}
\hline Month & 1 & 2 & 3 & 4 & 5 & 6 & 7 & 8 & 9 & 10 & 11 & 12 \\
\hline $\begin{array}{l}\text { No } \\
\text { shutter box }\end{array}$ & 2.2 & 3.0 & 6.7 & 10.1 & 14.3 & 17.9 & 21.8 & 21.6 & 18.3 & 13.5 & 7.4 & 4.2 \\
\hline Shutter box & 2.2 & 2.9 & 6.5 & 9.8 & 13.9 & 17.4 & 21.3 & 21.2 & 18.0 & 13.4 & 7.3 & 4.2 \\
\hline Difference & 0.0 & 0.1 & 0.2 & 0.3 & 0.4 & 0.5 & 0.5 & 0.4 & 0.3 & 0.1 & 0.1 & 0.0 \\
\hline
\end{tabular}

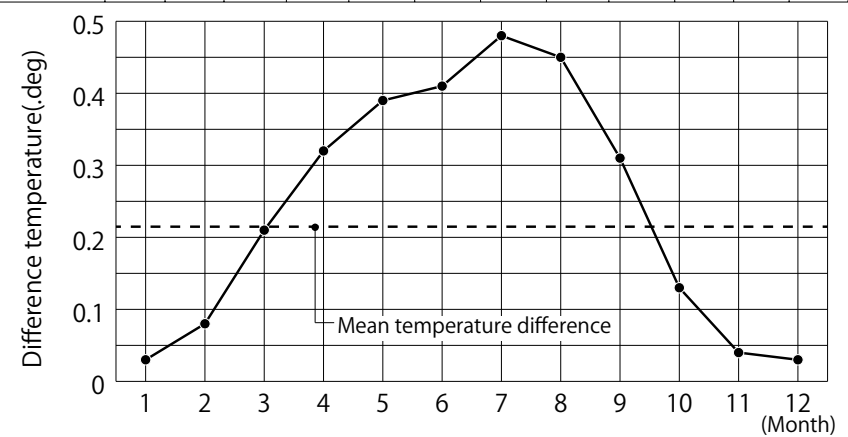

Fig. 11 Monthly average living temperature difference (chap.3.3)

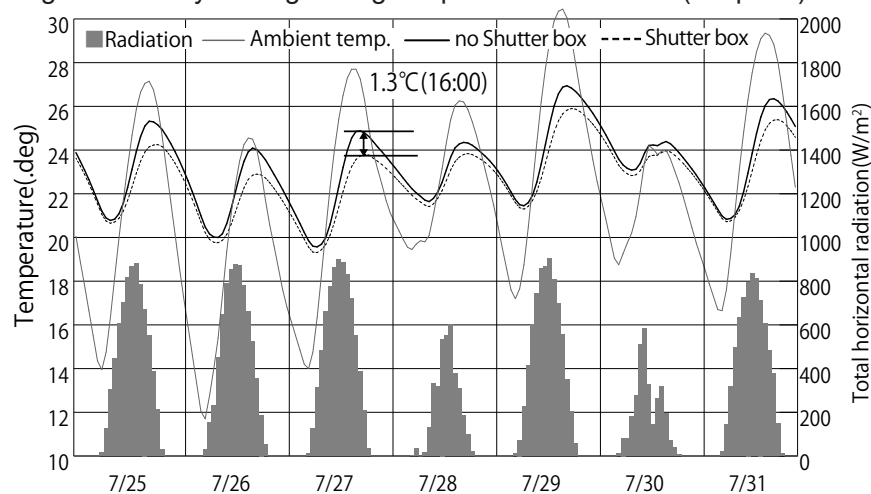

Fig. 12 Room temperature variation from $7 / 25$ to $7 / 31$ (chap.3.3)

Table 4 Room temperature on monthly average (Chap.3.4)

\begin{tabular}{|l|l|c|c|c|c|c|c|c|c|c|c|c|}
\hline Month & 1 & 2 & 3 & 4 & 5 & 6 & 7 & 8 & 9 & 10 & 11 & 12 \\
\hline $\begin{array}{l}\text { Shutter and } \\
\text { curtain }\end{array}$ & 2.2 & 3.0 & 6.6 & 9.9 & 14.0 & 17.6 & 21.4 & 21.3 & 18.1 & 13.5 & 7.4 & 4.3 \\
\hline No shutter & 2.2 & 2.9 & 6.5 & 9.8 & 13.9 & 17.4 & 21.3 & 21.2 & 18.0 & 13.4 & 7.3 & 4.2 \\
\hline Difference & 0.0 & 0.1 & 0.1 & 0.1 & 0.1 & 0.2 & 0.1 & 0.1 & 0.1 & 0.1 & 0.1 & 0.1 \\
\hline
\end{tabular}

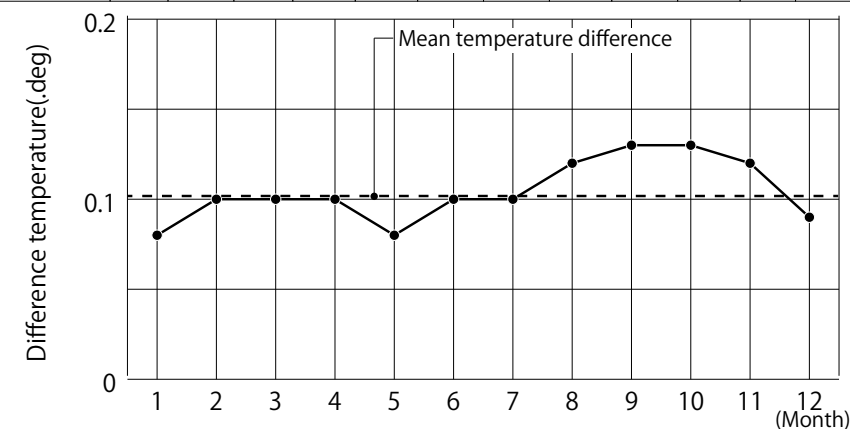

Fig. 13 Difference in monthly mean room temperature (chap.3.4)

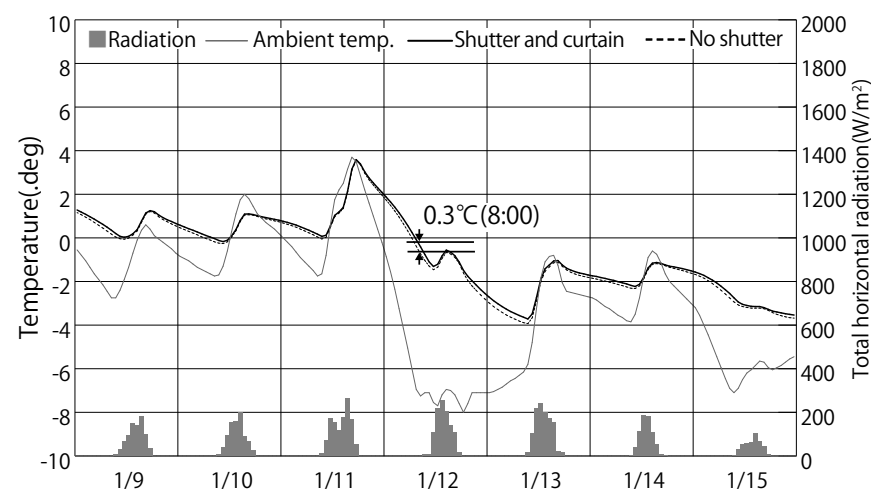

Fig. 14 Room temperature variation from $1 / 9$ to $1 / 15$ (chap.3.4) 
間の差が小さくなっている。回遊性と空間の伸縮は建築計画での特 長であるが、建築的工夫と環境制御の関係の視点で見ても、建具や 間仕切りの開閉で空間を伸縮することで、自然室温を約 $1{ }^{\circ} \mathrm{C}$ 変動で きることは、断熱性能の未熟な時代おいては有効な計画手法である と捉えることができる。

\section{3. 横長空と空周りの装置が室温に及ぼす影響}

横長空に付属するシャッターは小さな家以降の作品にはほとん ど見られないことから、実験的な試みであったことが推察される。 シャッターを収納するために横長空上部に設けられたシャッター ボックスは日射を遮蔽する装置として室温に影響を及ぼしていると 考えられるため、庇形状の日射遮蔽装置として室温に対する影響を 確認した。

3.2 で検討した建具や可動間仕切りを閉じて空間を小さくしたモデ ルにおいて、シャッターボックスの有無による自然室温変動の違い を比較すると、年間を通して居間の室温は、シャッターボックスが ない場合のほうが高い (Fig.8)。月別の居間の平均值を示す (Table3)。 7 月、8 月の平均值はいずれも $20^{\circ} \mathrm{C}$ を上回る。シャッターボックス の有無による居間の室温差に着目すると (Fig.11)、10 月から 3 月の 室温差は小さく、4 月から 9 月に室温差は大きくなる。 7 月、 8 月に おいては、太陽高度が高く、シャッターボックスが日射遮蔽装置と なって室温が上昇しないことから、室温差は大きくなっている。最 もモデル間で最も差が見られた 7 月下旬の一週間の室温変動に着目 すると (Fig.12)、最大で $7 / 27$ に $1.3^{\circ} \mathrm{C}$ の差が見られた。日本の最北 端よりも緯度が高く南中太陽高度は $67^{\circ}$ と低いが、夏は日射量が多 いことから庇としての効果が見られる。しかし、外気温は低いため、 庇形状の装置がない場合でも十分涼しくすごせると考えられる。一 方、日射がほとんど見込めない 11 月から 2 月の平均室温において、 両モデルに差はほとんど見られないが、日射が得られる期間におい て (Fig.12)、日射遮蔽装置としてのシャッターボックスは、室温上 昇を妨げるものとなり、中間期では温度が上昇せず効果が逆転する。 以降の作品でシャッターやシャッターボックスが見られなくなった

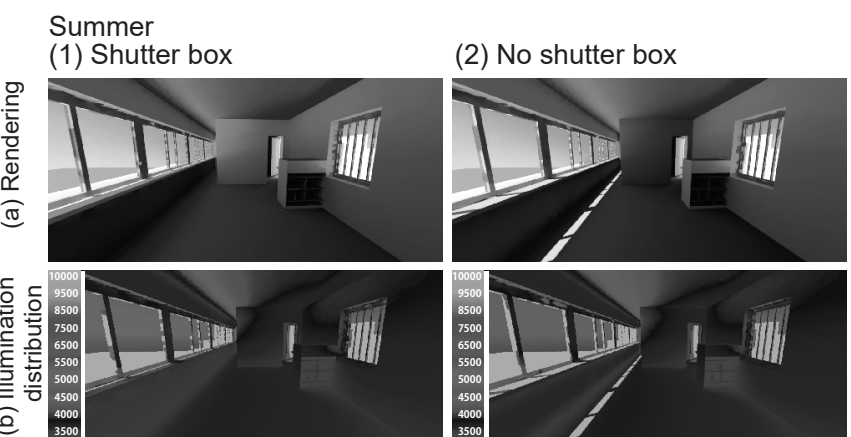
Winter (3) Shutter box

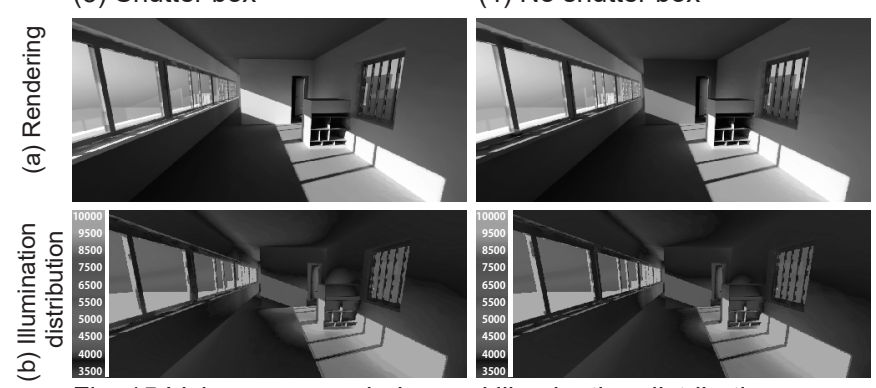

Fig. 15 Living room rendering and illumination distribution
のはこの点もひとつの要因となっているのではないかと考えられる。

\section{4. 夜間断熱装置としてのシャッター及びカーテンの効果}

冬期の外気温は季節を通して低く水点下となることもあり、さら に日射量も少ないことから日中の熱取得がなく、夜間の室温の低下 は特に著しいものとなる。断熱性能が弱い開口部において、外気温 が低下する夜間にシャッターやカーテンを用い、熱抵抗を大きくす ることで、夜間の室温低下が抑えられる。そこで、横長空の夜間断 熱戸としてのシャッターとカーテンが室温に及ぼす影響を検討する。 3.2 で検討し室温がより高い結果となった、建具を閉じて空間を小さ くしたモデルを用いて、横長空に対して、シャッターとカーテンの 両方を閉めた夜間断熱戸を設定し注 19), 注 20) 比較する (Fig.8)。

年間を通して居間の室温は、夜間断熱戸を閉めた場合のほうが高 い。月毎の居間の平均値を示す (Table4)。夜間断熱戸の有無のモデ ル間の温度差に着目すると (Fig.13)、8月から 10 月に室温差は大き くなるものの、その差は最大 $0.1{ }^{\circ} \mathrm{C}$ と概ね小さい。外気温が最も低い 1 月の 1 週間の室温変動に着目すると（Fig.14）、夜間、シャッター を閉じ、さらにカーテンを閉じることにより夜間に室温が上昇する。 最もモデル間で差が見られた 1 月中下旬の室温変動では、最大で $1 / 12$ に $0.3^{\circ} \mathrm{C}$ 差が見られた。室温が水点下を割り込み低温安定となって いるのは、断熱がない躯体の熱容量によるものと考えられる。実際 の生活では、空台の下に敷設されたラジェータが暖房システムとし て使用され、日中の温度上昇と熱容量による時間遅れが発生し、室 内に蓄熱効果をもたらしていたのではないかと考えられる。

\section{4. 光と建築計画}

2 章で検討した横長空に着目し、室内の光環境に自然光がどのよう な効果をもたらしているかをシミュレーションソフト注7)により検討 する。

\section{1. 横長空の光環境における効果}

光環境シミュレーションソフトを用いて、「小さな家」の居間にお ける昼光環境を検討した。モデルの作成にあたっては、位置を「小 さな家」の地点 ( 北緯 $46.52^{\circ}$, 東経 $6.67^{\circ}$ ) とし、夏は 6 月 21 日、冬 は 12 月 23 日の正午を検討日とした ${ }^{\text {注 }} 21$ 。夏と冬、日照の遮蔽を考慮 してシャッターボックスの有無の影響をレンダリングと照度分布に より確認した（Fig.15）。

夏、冬ともに、室内全域に均質な日照が得られており、横長空と 東西軸に長く配置した建築計画が室内の光環境に良好な効果をもた らしていることがわかる。また、夏の南中時に直達日射は室内に侵 入しないことから、シャッターボックスが日照を遮蔽する装置とし て機能していたと考えられる。シャッターボックスが無い場合は、 直達日射が室内に侵入して床面に到達する。冬はシャッターボック スの有無で光が侵入する状況の差はほとんどなく、日照は奥行きの 浅い室内の北端まで侵入し、北側の壁面に到達している。

これらのことから、光環境においては、シャッターボックスが室 内の光環境に悪影響を及ぼすことは少なかったと考えられるが、以 降の作品で、シャッター及びャッターボックスが採用されなくなっ ていった要因のひとつとして、前章での温熱環境における室温上昇 を妨げる影響が考えられる。一方で、横長空に沿った空台は以降の 作品にも見られ、ル・コルビュジエ作品の空周りを特徴付けている 要素でもある。シャッターボックスが無い場合には、横長空に沿っ 
た白色の窻台に反射した反射光によって天井面照度がわずかに高く なっており（Fig.15）、取り込んだ光を反射し室内に拡散する装置 として空台を設けていたことが推察される。後の作品における空周 りの日除けの工夫としては、室内に侵入する直射光を遮りながらも その面での反射光を導入する手法がブリーズソレイユにつながって いったのではないかと考えられる。

\section{5. 結}

本研究では、ル・コルビュジエの「小さな家」を対象に、ル・コルビュ ジエの建築的工夫と環境制御に対する思考、パッシブデザインの思 考の一端を明らかにするため、空間構成と熱・光環境の関係性を検 証した。

2 章の気候特性と建築的手法に関寸る分析では、気候条件を概観し、 さらに建物の配置計画と主空間の構成に着目するとともに、空の計 画、建物の構造と構法及び熱環境に関寸る構成材料について検討し た。一定の熱容量を持つ中空煉瓦、コンクリートブロック、コンクリー トで構成され、断熱材は使用されていなかったこと、また、主空間 に設置された横長空周りの構成など、建築計画と環境制御に関する 特徴を明らかにした。

3 章の熱環境に関する分析では、主空間の熱環境をシミュレーショ ンにより検証した。緑化された屋上の土はル・コルビュジエが期待 していた一定の断熱性能を有していることを確認した。また、建具 や可動間仕切りの開閉による空間の伸縮によって、室温調整の効果 があったことを確認した。さらに、夜間断熱戸として、シャッター とカーテンを利用した場合、夜間の温度低下が僅かに抑えられるこ とを示した。また、シャッターを外部に取り付けたことによって庇 形状を持つシャッターボックスは、夏期は日射遮蔽としての効果が みられるものの、この地域では中間期や冬期において、室内の温度 上昇を妨げる働きをすることを示した。これは、同様の気候帯にお ける以降の作品で日射遮蔽を意図したシャッターとシャッターボッ クスが見られなくなったことの一因とも考えられる。

4 章の光環境に関寸る分析では、2 章で分析した横長空に着目し、 自然光のシミュレーションにより室内にもたらす光環境の効果を検 討した。東西に長い横長空によって、光を一様に採り入れることが できており、空に設けられた奥行き $250 \mathrm{~mm}$ の白色の空台による反 射光が室内の光環境に一定の効果を生んでいることも示した。また、 庇形状のシャッターボックスが日照を遮蔽する効果はわずかである ことも確認された。以降の作品でも見られる、庇のない横長空と空 台の組み合わせは環境制御の要素と考えられる。

以上、本研究で明らかにしたル・コルビュジエの「小さな家」に おける環境に対する建築的工夫と環境制御の関係には、躯体性能・ 断熱性能などが未熟な時代において、緑化された屋上、屋上庭園に よる断熱性の向上、空間配置や建具の開閉による空間の伸縮といっ た建築計画的工夫、自由な平面によって室内環境を制御する意図と その効果が確認された。また、光環境においては、横長空、水平連 続空と空周りの工夫によって良好な光環境が作られていることを明 らかにした。これは、横長空が単なる景観の切り取りや古典的構造 からの解放といった、横に長い空という形状だけにとどまらないこ とを示している。以上のように、国際様式の原則として考案された 近代建築の 5 原則の、屋上庭園、自由な平面、水平連続窓は、室内
環境を向上寸る建築的工夫としての側面も持ち、現代における設計 手法を思考する上で、環境デザイン的側面から再考される有用なパッ シブデザイン手法の概念を内包していると考えられる。

本研究では扱わなかった風環境についてもル・コルビュジエの環 境に対する建築的工夫と環境制御の関係に大きく影響を与えている と考えられる。また、「小さな家」と後の作品との比較、検討するこ とにより体系的に環境制御と建築計画との関係を考察するなど、本 稿とは異なる視点からの考察も可能であり、今後の研究により明ら かにしていく予定である。

\section{注}

注1）近代建築の発達に大きな影響を与えた、ル・コルビュジェが提唱し た近代建築の $5 つ$ の原則に、ピロティ、屋上庭園、自由な平面、水平連 続空、自由なファサードがある。1927年、『Zwei Wohnhäuser von Le Corbusier und Pierre Jeanneret』の序文にて初めて発表された。 "Les 5 points d'une architecture nouvelle"を、参考文献2) p.114115 では直訳されており「新しい建築の5つの要点」となっている。

注2）オザンファン邸（パリ・フランス）では、トップライトからの光を制 御し、北、東の大きなガラス面から天空光を取り込むことで安定した光空 間となっている。

注3）サラバイ邸（アーメダバード・インド）では、居室に連続する広いバ ルコニーによって日影の領域を作り、開口の工夫で通風を促進している。

注4）クルチェット邸（ラプラタ・アルゼンチン）では、太陽の軌道に配慮 し公園に面寸るファサードに日除け、ブリーズ・ソレイユを設けている。

注5）参考文献4）p.235でル・コルビュジエは「身体の諸器官に作用し、感 受性を刺激するさまざまな形のエネルギーをうまく利用することが必用で ある。」と述べている。

注6）参考文献5）p.26でル・コルビュジエは、外部の湖際に設けた壁と開 口について「ただし南側の壁には均整をとるために正方形の穴をうがった。 （中略）日陰をつくるのと同時に新鮮な冷気をもたらすものでもある。」 と述べるなど、建築的工夫と環境制御の統合を意図した表現がみられる。

注7）非定常の多数室温熱環境シミュレーションソフトTRNSYS18を熱 環境の検討に用いている。Radianceを光環境の検討に使用した。なお、 TRNSYS18は、国土交通省の特別評価方法認定（年間暖冷房負荷の計算 方法を用いて評価する方法) を取得している(認定番号329)。

注8）参考文献2）pp６7-68，13）,14）,15）,16)

注9）居間、寝室、浴室は一室空間であり、これらの空間を対象とした。 注10）TRNSYS18に付属されているMeteonorm社のピュリーの気象データ を用いて作成した。温熱計算にもこの気象データを用いている。東京の気 象デー夕は、参考文献17）標準年EA気象デー夕1995年版 (東京)を用いた。 注11）参考文献11）において、参考文献18）の年平均全天日射量の図より 平均的な地点として東京を選択し、東京のパッシブ気候図より夏期の日射 量が多い值を $550 \mathrm{~W} / \mathrm{m}^{2}$ と定義している。また、日本の 842 地点の気象デー タより作成したパッシブ気候図では、年中 $450 \mathrm{~W} / \mathrm{m}^{2}$ を下回る地点が $3 \%$ と 少数であったことから、日射量が少ない值を $450 \mathrm{~W} / \mathrm{m}^{2}$ とした。

注12）参考文献19）気象庁において、最高気温が $35^{\circ} \mathrm{C}$ 以上の日を猛暑日、 $30^{\circ} \mathrm{C}$ 以上の日を真夏日、 $25^{\circ} \mathrm{C}$ 以上の日を夏日、 $0^{\circ} \mathrm{C}$ 未満の日を真冬日、ま た、最低気温が $0^{\circ} \mathrm{C}$ 末満の日を冬日と定義されている。

注13）後に近代建築の 5 原則として、水平連続空を発表するが、「小さな 家」の横長空をル・コルビュジエは水平連続空として説明してないことか ら、この表現としている。

注14）参考文献5）p.35でル・コルビュジエは「巻き上げ式の鎧戸は、巻き 上げ機構もそのガイドレールも外部にとりつけたので、その伝統的な格納 庫から泠たい空気が家の中に侵入するのを防ぐことができた。と述べて いる。

注15）参考文献15）をもとに断面詳細に関し作成した。

注16）参考文献13）,14）,15）

注17）計算に関わる条件として、各部位の仕様は注15）をもとに設定し、 材料の熱物性值は参考文献20）、日射吸収率は参考文献21）,22）上り設 定した。また、気密性は参考文献23）より、当時の性能と1月のピュリー の外界条件から想定し換気回数 1.2 回/ $\mathrm{h}$ とした。間仕切りがない部分の室 間換気の風量は参考文献24）、家具の顕熱容量は参考文献25）を用いて 
考慮している。地中温度は深さによって温度変動が異なること考慮し、参 考文献26）より、地下床面 (深さ $2 \mathrm{~m}$ )、壁面 (深さ $1 \mathrm{~m}$ )、地表面近く(深さ $0.5 \mathrm{~m})$ と分けて設定した。建物周辺の日射障害物として西側の塀を設定し た。

注18）熱貫流率は、室内側総合熱伝達率 $\alpha_{\mathrm{i}}=7.7 \mathrm{~W} /\left(\mathrm{m}^{2} \cdot \mathrm{K}\right)$, 室外側総合熱伝 達率 $\alpha_{0}=25.0 \mathrm{~W} /\left(\mathrm{m}^{2} \cdot \mathrm{K}\right)$, 材料の熱伝導率は参考文献20）の值を用いて算 出した。

注19）参考文献27）より、開口部は木製サッシ十単板ガラス $(4 \mathrm{~mm})$ の熱貫 流率を $5.205 \mathrm{~W} / \mathrm{m}^{2} \mathrm{~K}$ 、鋼製シャッターの熱抵抗值 $0.101 \mathrm{~m}^{2} \mathrm{~K} / \mathrm{W}$ ，カーテン+ レースの熱抵抗值 $0.023 \mathrm{~m}^{2} \mathrm{~K} / \mathrm{W}$ 設定し、参考文献28）より付属部材が付 与された開口部の熱貫流率を算出し、 $3.16 \mathrm{~W} / \mathrm{m}^{2} \mathrm{~K}$ とした。

注20）日の出日の入り時刻が時期によって異なることから、水平面全天日 射量が0となる時間帯を夜間とした。

注21）照度は、CIE標準晴天照度より算出している。視点及び視線は、床か ら $1.5 \mathrm{~m} の$ 点で、客用居間兼寝室側から居間の横長空の方向とした。日射 吸収率は参考文献21），22）より設定した。

\section{参考文献}

1) Agency for Natural Resources and Energy: Energy supply and demand results 2012, 2012

資源エネルギー庁：平成 24 年度におけるエネルギー需給実績, 2012

2) Le Corbusier, Yoshizaka Takamasa: The complete works of Le Corbusier Vol.1 1910-1929, A.D.A EDITA Tokyo, pp.67-68, 114115,1979

ル・コルビュジェ, 吉阪隆正(翻訳)：ル・コルビュジェ全作品集 第1卷 1910-1929, A.D.A EDITA Tokyo, pp.67-68, 114-115, 1979

3) Le Corbusier, De Pierrefeu, Nishizawa Shinya: Ningennoie SD 120 (La maison des hommes), Kajima Institute Publishing, pp.133, 141, 1977

ル・コルビュジエ, $\mathrm{F} ・$ ド・ピエールフウ，西澤 信爾(翻訳）：人間の家 SD選書 120, 鹿島出版会, pp.133, 141, 1977

4) Le Corbusier, Sakakura Junzo: Kagayakutoshi SD 33 (Maniére de penser l'urbanisme), Kajima Institute Publishing, p.235, 1968

ル・コルビュジェ, 坂倉 準三 (翻訳)：輝く都市 $\mathrm{SD}$ 選書 33 , 鹿島出版 会, p.235, 1968

5) Le Corbusier, Morita Kazutoshi: Chiisanaie:1923 (Une petite maison), Shubunsha, pp.5, 7, 18, 41, 1980

ル・コルビュジェ, 森田一敏(翻訳)：小さな家：1923, 集文社, pp.5，7, $18,26,35,41,1980$

6) Sendai Shoichiro, Suzuki Motohiro: The Theory on Architectural Color and the Notion of Environment by Le Corbusier, Journal of Architectural Planning (Transactions of AIJ), Vol.69, No.582, pp.185-191, 2004.8.

千代章一郎, 鈴木基紘：ル・コルビュジエの建築色彩理論と環境概念, 日 本建築学会計画系論文集，第69巻，第582号，pp.185-191，2004.8

7) Ohno Takashi, Kawamukai Masato: A study on Le Corbusier's housing concept for the urban project in Chandigarh: Le Corbusier's housing design referring to vernacular elements, Journal of Architectural Planning (Transactions of AIJ), Vol.77, No.671, pp.183-191, 2012.1

大野隆司, 川向正人：チャンディガール州都計画におけるル・コルビュジ エの住宅構想に関する研究：土着的な要素を取り入れた住宅設計, 日本建 築学会計画系論文集, 第77巻, 第671号, pp.183-191, 2012.1

8) Matsubara Naoki, Yoshioka Tomoko, Matsubara Sayoko, Kurazumi Yoshihito: Classification of the technology of environment: Conscious house and the design method of space, AIJ Journal of Technology and Design, No.11, vol.22, pp.425$428,2005.12$

松原斎樹，吉岡智子，松原小夜子，藏澄美仁：環境住宅の技術と空間設計 手法の類型化：1970 1995年の日本の住宅の分析，日本建築学会技術報 告集, 第11巻, 第 22 号, pp.425-428, 2005.12

9) Suzuki Masaaki, Ichikawa Takanori: A study on passive design techniques and the selection factors of modern houses, Journal of Environmental Engineering (Transactions of AIJ), Vol.74, No.642, pp.1001-1008, 2009.8
鈴木聖明，市川尚紀：現代住宅のパッシブ設計手法とその選定要因に 関する事例調査研究, 日本建築学会環境系論文集, 第 74 巻, 第 642 号, pp.1001-1008, 2009.8

10) Koizumi Takashi, Suzuki Nobuhiro: Effects of the sunlight on spatial orders and their causes in architectural spaces, Journal of Architecture, Planning and Environmental Engineering (Transactions of AIJ), Vol.64, No.516, pp.153-160, 1999.2 小泉隆，鈴木信宏：建築空間における空間秩序的太陽光効果とそれらの要 因, 日本建築学会計画系論文集, 第64巻, 第516号, pp.153-160, 1999.2

11) Matsumoto Yoshie, Kodama Yuichiro, Takemasa Koji, Murata Ryo, Kaneko Naoshi, Miyaoka Futoshi: Development and application of passive climate chart, Journal of Environmental Engineering (Transactions of AIJ), Vol.82, No.737, pp.653-662, 2017.7

松元良枝，小玉祐一郎，武政孝治，村田涼，金子尚志，宮岡大：パッシブ 気候図の作成とパッシブデザインへの活用，日本建築学会環境系論文集， 第82巻, 第737号, pp.653-662, 2017.7

12) Kaneko Naoshi, Koizumi Masao, Takemasa Koji, Matsumoto Yoshie: Daylight control at Villa Le Lac by Le Corbusier, Summaries of Technical Papers of Annual Meeting, Architectural Institute of Japan, Architectural planning and design, pp.409$410,2020.7$

金子尚志，小泉雅生，武政孝治，松元良枝：ル・コルビュジエの小さな家 (Villa Le Lac) における光環境, 日本建築学会大会学術講演梗概集 建 築計画, pp.409-410, 2020.7

13) Echelle-1, Fondation Le Corbusier: LE CORBUSIER PLANS (LE CORBUSIER PLANS impressions) 2:1905 1930, pp.9-21, 2005

エシェル・アンル・コルビュジェ財団：ル・コルビュジェ网面集 vol.2 住宅 II $: 1905$ 年 $\sim 1930$ 年, pp. 9-21，2005

14) Foundation Le Corbusier: LE CORBUSIER PLANS DVD Vol.1, Echelle-1, 2005

ル・コルビュジェ財団:ル・コルビュジェプランズ設計資料集成DVD Vol.1, エシェル・アン, 2005

15) Edward R. Ford, Yagi Koji: The Details of Modern Architecture 1, Maruzen Publishing, p.237, 1999.3

エドワード・R・フォード，八木幸二(監訳) :巨匠たちのディテールVol.1, 丸善出版, p.237, 1999.3

16) Steven Park, Tadokoro Shinnosuke, Suga Shiori: LE CORBUSIER REDRAWN THE HOUSES, x-knowledge, pp.16-25, 2013

スティーヴン パーク (著), 田所辰之助(監修), 菅しおり(翻訳)：ル・コ ルビュジェの住宅 3Dパース全集, エクスナレッジ, pp.16-25, 2013

17) Architectural Institute of Japan: Expanded AMeDAS Weather Data 1981-2000, Kagoshima TLO, 2005.8

社団法人日本建築学会：拡張アメダス気象データ 1981-2000, 鹿児島 TLO, 2005.8

18) NEDO: Database on solar radiation, 〈https://www.nedo. go.jp/library/nissharyou.html $>$ (accessed 2020.10.25)

NEDO：日射に関するデータベース,く https://www.nedo.go.jp/ library/nissharyou.html >, (参照 2020.10.25)

19) Japan Meteorological Agency: About temperature, < https:// www.jma.go.jp/jma/kishou/know/faq/faq3.html>, (accessed 2020.10.25)

気象庁：気温について, < https://www.jma.go.jp/jma/kishou/know/ faq/faq3.html $>$, (参照 2020.10.25)

20) SHASEJ: SHASE-G1001-2012 Heating Air-Conditioning Sanitary engineers' Program for Experience and Education, SHASEJ, pp.40-41, 2012.10

公益社団法人空気調和・衛生工学会：試して学ぶ熱負荷HASPEE〜新最 大熱負荷計算法〜，丸善出版，pp.40-41，2012.10

21) Tanaka Shunroku, Takeda Hitoshi, Iwata Toshie, Tsuchiya Takao: Building environmental engineering, INOUESHOIN, p.182, 2013.3

田中俊六, 武田仁, 岩田利枝, 土屋喬雄, 寺尾道仁 : 最新建築環境工学改 訂2版，井上書院，p.182，2013.3 
22) Hoyano Akira, Shirai Kazuyoshi, Nobuhiro Otsuka, Iwamura Kazuo: Indoor thermal control effect of rooftop lawn planting with thin soil layer on a wooden building, Journal of Architecture, Planning and Environmental Engineering (Transactions of AIJ), Vol.65, No.527, pp.15-20, 2002.1 梅干野晃，白井一義，大塚修弘，岩村和夫：薄い盛土層を持った屋上芝生 植栽の木造建物における室内熱環境調整効果, 日本建築学会計画系論文 集，第65巻，第527号，pp.15-20，2002.01

23) IBEC: New Energy Conservation Standards and Guidelines for Homes, ver.6, pp.109-120, 1997.8

財) 住宅・建築省エネルギー機構 : 住宅の新省エネルギー基準と指針 改 訂6版, pp.109-120, 1997.8

24) Serikawa Mao, Satoh Makoto, Nagai Tatsuo, Akimoto Takashi: Evaluation of energy consumption and health hazards in residential houses: part.1 Investigation of high insulation and air tightness in detached houses using time series heat load simulation, Journal of Environmental Engineering (Transactions of AIJ), Vol.82, No.733, pp.227-235, 2017.3

芹川真緒，佐藤誠，長井達夫，秋元孝之：住宅エネルギー消費量と健康性 の評価に対する研究：熱負荷シミュレーションを使用した戸建住宅の高 断熱化・高気密化に関する検討 その 1 , 日本建築学会環境系論文集，第 82 巻, 第733号, pp.227-235, 2017.3

25) Hyokakyoukai: Test guidelines for thermal environments (Annual heating and cooling load calculation method) by benchmark test results, p.16, 2004.4

〈http://www.hyoukakyoukai.or.jp/teikyo_joho/pdf/guide_benchi_ onnetsu.pdf >, (accessed 2020.12.8)

住宅性能評価機関等連絡協議会：ベンチマークテストの結果による温熱 環境 (年間暖冷房負荷計算方法)に関する試験ガイドライン, p.16, 2004.4 〈http://www.hyoukakyoukai.or.jp/teikyo_joho/pdf/guide_benchi_ onnetsu.pdf $>$, (参照 2020.12.8)

26) ASHRAE.: Chapter 31- Geothermal Energy. In: ASHRAE Handbook: Heating, Ventilating and Air-Conditioning APPLICATIONS, 1999.

27) Shimizu Norio: Study on thermal performance improvement of window, Technical papers of annual meeting, the Society of Heating, Air-Conditioning and Sanitary Engineers of Japan, pp.129-132, 2016.9

清水則夫：開口部の断熱性能向上に関する研究，空気調和・衛生工学会大 会学術講演論文集, pp.129-132, 2016.9

28) Building Research Institute: Technical information on the evaluation of energy consumption performance in compliance with the Energy Conservation Standard, pp.3-3-7, 3-3-8, 2016.4 国立研究開発法人建築研究所：平成 28 年省エネルギー基準に準拠したエ ネルギー消費性能の評価に関する技術情報（住宅）:2.1。熱貫流率及び線 熱貫流率，pp.3-3-7，3-3-8，2016.4 


\author{
Naoshi KANEKO ${ }^{* 1}$, Masao KOIZUMI ${ }^{* 2}$, Yoshie MATSUMOTO *3 \\ and Koji TAKEMASA*4 \\ ${ }^{* 1}$ Doctoral Student, Dept. of Architecture, Tokyo Metropolitan University, M.Design \\ *2 Prof., Dept. of Architecture, Tokyo Metropolitan University, Dr.Eng. \\ *3 Quattro Corporate Design, Co., Ltd., Dr.Eng. \\ ${ }^{* 4}$ Leader, LEAD Labo., Dr.Eng.
}

Introduction

Le Corbusier (1987-1965) is widely known for his concepts and methods of architectural design such as the Five Points of Architecture, Brise Soleil, Modulor, etc. An overview of Le Corbusier's work from the perspective of environmental considerations reveal examples of architectural ingenuity integrated into a design to control the environment. When Le Corbusier began his career as an architect, he intended to use natural lighting and ventilation to improve the environment and health in densely populated urban areas in the early 20th century. However, the architectural innovations such as natural lighting and ventilation, and the expression of cross-sectional diagrams may have had a considerable impact on the passive design that became popular in later years.

Methods:

This study examines features related to architectural planning and environmental control such as spatial features and the composition of the horizontal continuous window surround in Le Corbusier's "Une Petite Maison". In addition, the thermal and light environment produced by simulation software for the main rooms will be examined. It will reveal the relationship between Le Corbusier's architectural ingenuity and environmental control over the environment and some of the thinking that led to contemporary passive design which was active in an era before the building performance of the outer skin and equipment was inadequate and the energy was plentiful and stable.

Results:

1) The features related to architectural planning and environmental control such as the configuration around the horizontal continuous windows in the main space was identified. The building consisted of hollow brick, concrete block and concrete with a constant thermal capacity, and no insulation was used.

2) The soil for the rooftop greening was found to have a certain level of insulation performance. The expansion and contraction of the space by opening and closing fittings and movable partitions was confirmed to have an effect on room temperature control. Furthermore, the use of shutters and curtains slightly reduced the temperature drop at night. It was also shown that the shutter box attached to the outside is effective as a sunshade in summer, but prevents the temperature rise inside the room in the middle of the year and in winter in this area.

3) The horizontal windows allowing the light to enter uniformly and the reflected light from the white window sills on the windows has a certain effect on the indoor lighting environment. It was also confirmed that the effect of the eave-shaped shutter boxes on solar radiation shielding is minimal. The combination of a continuous horizontal window and window sill without shelter is also seen in later works.

In this study, the intention and effect of controlling the indoor environment by means of "roof terrace" to improve thermal insulation, architectural planning devices such as spatial arrangement and expansion and contraction of space by opening and closing fittings, and "the free plan" were confirmed. On the light environment, it was clarified that a good light environment was created by "the horizontal continuous window" and innovations around the windows.

Some of the Five Points of Architecture, devised as principles of the international style, also have aspects as architectural devices to enhance the indoor environment, and they seem to encompass the concept of a useful passive design approach that should be reconsidered from an environmental design standpoint when thinking about contemporary design practices. 